\title{
Diet of the cloud forest shrew Cryptotis meridensis (Insectivora: Soricidae) in the Venezuelan Andes
}

\author{
Amelia DÍAZ DE PASCUAL and Antonio A. DE ASCENÇÃO
}

Díaz de Pascual A. and De Ascençáo A. A. 2000. Diet of the cloud forest shrew Cryptotis meridensis (Insectivora: Soricidae) in the Venezuelan Andes. Acta Theriologica 45: $13-24$.

The diet of Cryptotis meridensis Thomas, 1898 was studied by analysing stomach contents of 55 shrews collected by pitfall trapping in the cloud forest of Monte Zerpa, Mérida, Venezuela. The aims of the study were to describe the diet of this unknown tropical species and test the prediction that this species should be more of a subterranean feeder according to its morphological adaptations. The diet was composed of 35 different prey taxa distributed in six invertebrate classes (Gastropoda, Annelida, Arachnida, Crustacea, Myriapoda and Insecta). The most important components of the diet were hypogeal invertebrates: Oligochaeta, Gastropoda, Theraposidae, Isopoda, Scolopendridae, Phasmatidae, Blatiidae, Lepidoptera larvae and pupae, Diptera larvae, adult Carabidae, Staphilinidae, Elateridae larvae, Passalidae and Scarabaeidae larvae. Their contribution was $69.44 \%$ of the overall diet composition. Oligochaeta were the most frequent prey. Ephigeal invertebrates (Lycosidae, Acrididae, Gryllidae, adult Scarabaeidae and Lycosidae) accounted for only $27.24 \%$. The preferences for soil invertebrates found in this study confirmed our prediction that $C$. meridensis uses mostly a subterranean foraging mode in accord with its morphological adaptations similar to other shrews in temperate habitats.

Departamento de Biología, Facultad de Ciencias. Universidad de Los Andes, Mérida 5101,Venezuela,e-mail: adiaz@ciens.ula.ve,e-mail: ascencao@ciens.ula.ve

Key words: Cryptotis meridensis, diet, foraging mode, cloud forest, Andes, Venezuela

\section{Introduction}

Two shrew species have been recordered in Venezuela: Cryptotis meridensis Thomas, 1898 which is a typical species from the Andes of Mérida and Cryptotis thomasi (Merriam, 1897) that has been found in the Perijá range (Duarte and Viloria 1992, Soriano et al. 1999). C. meridensis occurs in cloud forests and páramo habitats (Durant and Péfaur 1984, Linares 1998). This is a small-sized shrew (with an average of body mass of $11.5 \mathrm{~g}$ ), with a long and pointed rostrum, very small eyes, a short tail, short feet bearing long claws for digging and very small ears and dense pelage. All these morphological adaptations indicate that it is an insectivorous animal living in burrows and underground tunnels, as do other congeneric species (Pernetta 1977, Hutterer 1985, Barnett 1992).

The restricted distribution range of $C$. meridensis, along with its secretive habits and the need for special collection methodology, have been the main reasons 
why this shrew has remained unstudied compared with temperate species (Rose 1980, Durant and Péfaur 1984, Barnett 1992, Linares 1998). However, some ecological observations have been published on two congeneric species from the Andes, Cryptotis montivaga in Ecuador (Barnett 1992) and Cryptotis thomasi in Colombia (López-Arévalo et al. 1993). These two species are more frequently captured in the páramo than in the forest. Comparatively little information is available for tropical species which may also be related to its scarcity throughout its geographical range.

Leaf litter invertebrates in the cloud forest are extremely abundant and diverse as in other tropical environments (Leigh et al. 1982, Adis 1981, 1988). Unfortunately, little work has been done in ecological studies on the arthropods in the cloud forest, especially in those living in leaf litter. A study on dung beetles is the only one that has been done in the cloud forest of Mérida. It has been shown that the activity of the dung beetle community lasts throughout the year on account of seasonal replacement of species according to the rainfall cycle with species having overlapping generations (De Ascenção 1997). From this result some assumptions can be made: (1) The abundance of invertebrates living in a relatively sheltered and stable microenvironment such as leaf litter should be less affected by seasonal changes in the food resources as usually occur in other microhabitats (as tree crowns, ground surface, soil). (2) Seasonal fluctuations of their populations are not necessarily of a catastrophic nature (Wolda 1981, Leigh et al. 1982, Levings and Windsor 1984). A study of the assemblage pattern in Sphingidae, the immature stages of which are found in leaf litter, showed that the community consisted of forty species with varying body size distribution and that the small sized species were the most abundant (Narváez and Soriano 1996).

Based on the above information, we predicted that $C$. meridensis should be a wide range feeder taking subterranean and surface dwelling prey according to its morphological adaptations.

\section{Material and methods}

\section{Study area}

The Monte Zerpa "cloud forest" is located in the Sierra del Norte of La Culata range, at $8^{\circ} 37^{\prime} \mathrm{N}$ and $71^{\circ} 10^{\prime} \mathrm{W}$, from 2.000 to $2.800 \mathrm{~m}$. Although it is part of a continuous belt of cloud forest, the area known as Monte Zerpa is estimated to be 900 hectares (Durant 1993). Climatic data was taken from the nearest meteorological station (Santa Rosa) located at $1 \mathrm{~km}$ from the forest at $1.950 \mathrm{~m}$ altitude (Fig. 1). High precipitation and constant moderate temperature are the main characteristics of the climate of this environment. Two wet periods occur from March to June, with a maximum precipitation in May, and from August to December, with a maximum in October. One dry season runs from January to March, with the lowest rainfall value in January. Another very short dry spell occurs in July (Fig. 2). Associated factors, such as daily mist and fog, result in high relative humidity that moderates diurnal temperature variations and reduces insolation.

The term cloud forest is used to encompass a complex variety of hygrophilous forests that constitute the upper limits of the continuous forests of the Andes. The trees of the cloud forest, which range from 25 to $35 \mathrm{~m}$ in height and 40 to 60 species per ha, produce an irregular aspect with great 


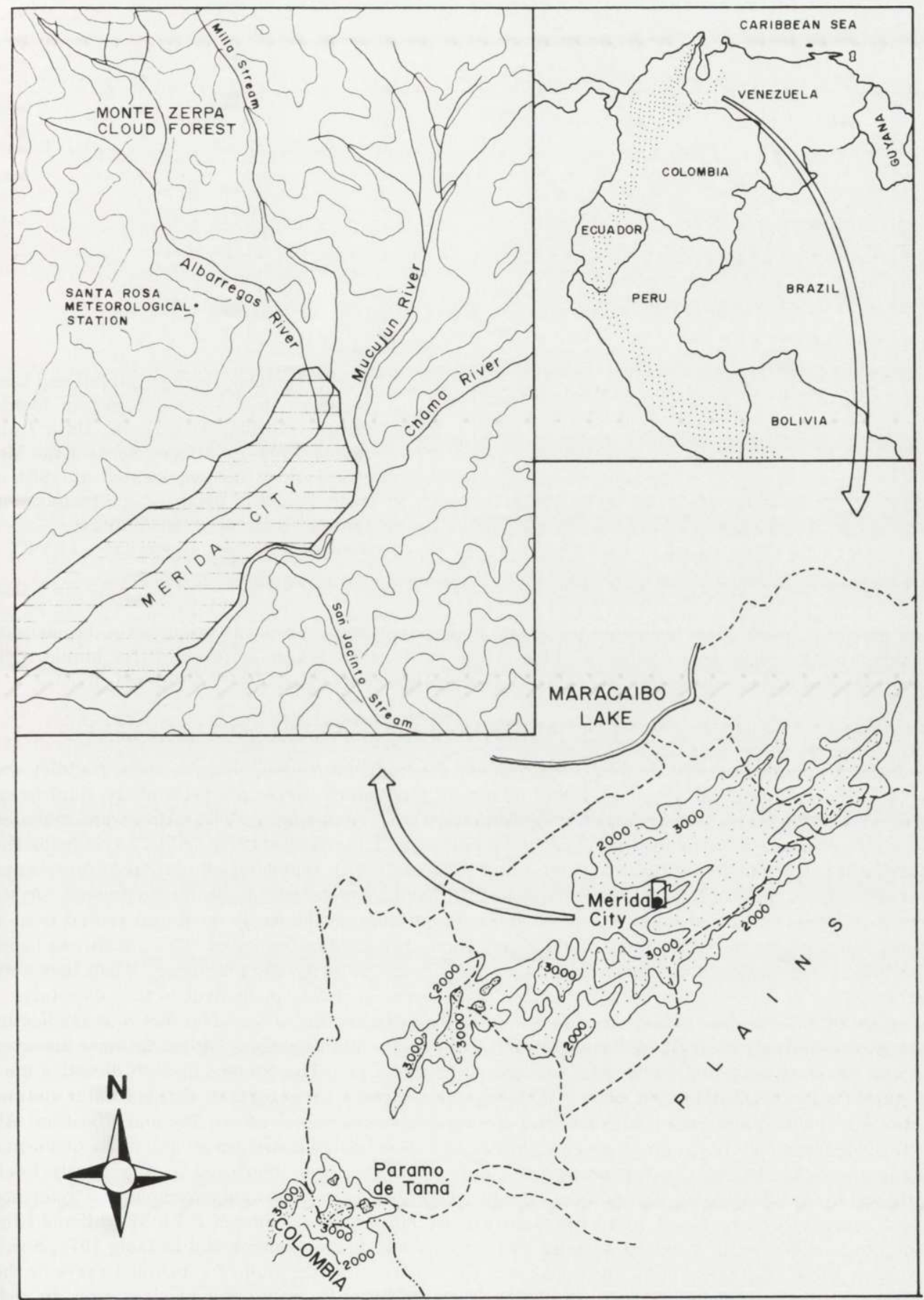

Fig 1. Geographical situation of Monte Zerpa cloud forest, Mérida, Venezuela. 


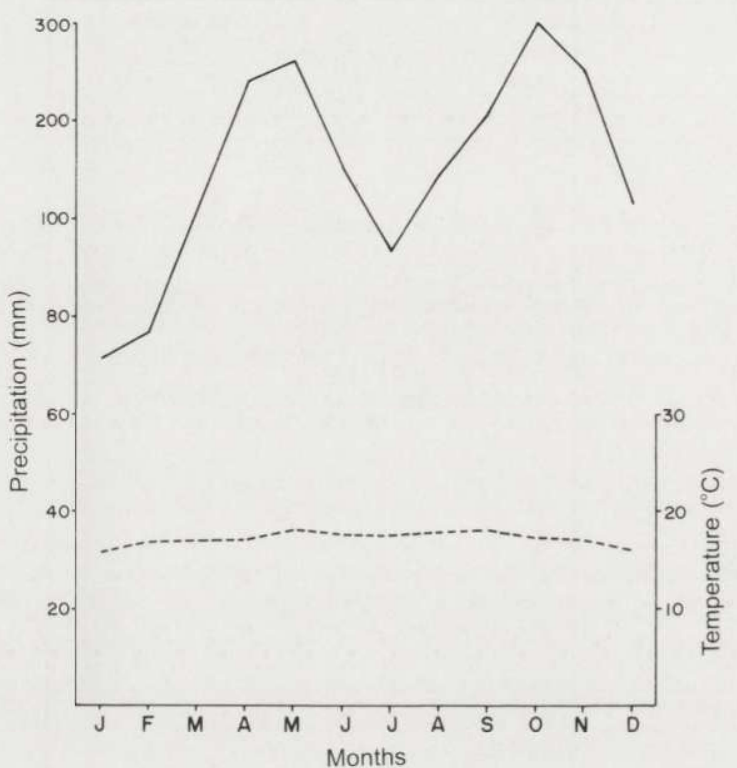

Fig. 2. Monthly average rainfall and temperature in the cloud forest of Monte Zerpa, Mérida, Venezuela. Data from period 1968-1995 from Santa Rosa Meteorological Station, located at $1950 \mathrm{~m}$ a.s.l. Symbols used: — Precipitation (annual average $-2011 \mathrm{~mm}$ ), .... Temperature (anual average $-17.1^{\circ} \mathrm{C}$ ).

plant species richness. Most trees have leaves throughout the year and bear many epiphytes (bromeliads, orchids, araceas, piperaceas and ferns). One of the most characteristic features of this humid environment is the presence of tree ferns (Ataroff and Schwarzkopf 1992).

\section{Methods}

Pitfall trapping was used as an efficient method for capturing shrews (French 1984, Handley and Kalko 1993, Kirkland and Sheppard 1994). In a 1 ha plot, which represents $0.1 \%$ of the total forest surface, 94 pitfall traps were arranged in a grid pattern with $10 \mathrm{~m}$ spacing. The pitfall traps consisted of metallic containers $31 \mathrm{~cm}$ deep and $25 \mathrm{~cm}$ in diameter, with two lateral holes drilled $15 \mathrm{~cm}$ below the upper edge to prevent the containers from filling completely with rainwater and any resultant escape of animals. Each trap contained 1 litre of $10 \%$ formalin and $2 \mathrm{~g}$ of detergent powder (to prevent corpses from floating and being available to scavengers). Traps were permanently open and visited twice a month, but captures were accumulated bimonthly from April 1988 to December 1995. All shrews found in the traps were weighed and measured, examined for sex, maturity and pregnancy. Then they were dissected to extract the digestive tracts and finally preserved in $10 \%$ formaldehyde in the laboratory.

In total, 353 specimens of $C$. meridensis were captured in this study. The diet was studied by analyzing of 55 completely filled digestive tracts ( 27 females and 28 males). Stomachs were dissected and the complete contents removed for analysis of food remains. The content of each digestive tract was preserved in a solution of six parts of $95 \%$ isopropilic alcohol, three parts of distilled water and one part of $40 \%$ phenol, and then identified using a stereoscopic microscope ( $4 \times$ to $25 \times$ magnification). All identifiable fragments (legs, wings, cerci, antennae and other cephalic structures) and other taxonomic diagnostic structures of the consumed prey were separated and identified at the family level. Taxonomic identification of the animal remains were made by using an entomological reference collection from the same forest, literature on arthropod morphology (Chapman 1971, Metcalf and Flint 1985, Osuna 1995) and taxonomic keys for terrestrial invertebrates (Borror and DeLong 1971, Smith and Silva 1983, Whitaker 1988). In some cases the differential digestion of consumed preys or the extreme fragmentation of the same, allowed their identification to only order or class level. In each digestive tract the minimum number of prey consumed per taxonomic group was estimated by reconstruction and ordering of all the fragments found (Whitaker 1988). 
The diet was summarised in four ways: (1) frequency of each prey taxum in all digestive tracts $(\mathrm{N})$, (2) the proportion of the total number of each prey taxum compared with the total occurrences of all categories (A), (3) the proportion of all prey taxum grouped in each taxonomic order related to the total number of categories (B), (4) the proportion of shrews that consumed each prey taxum related to the total number of shrews analysed (C). The main prey taxa in the diet were determined selecting those taxa that were eaten by more than $20 \%$ of the shrews (Craig 1991).

To determine the importance and variation of the different trophic components we used the method developed by Pielou (1975). This method requires a matrix, where rows represent different types of food or prey taxa, and columns represent the number of prey items for each prey taxum found for every four stomachs studied. With this matrix we calculated the shrew diet diversity for each group of four stomachs through the Shannon-Wiener diversity index $\left(H^{\prime}\right)$, that is defined as:

$$
H^{\prime}=-\sum_{i=1}^{s}\left(p_{i} \ln p_{i}\right)
$$

where $p_{i}$ is the proportion of food units or prey items in a certain type of prey taxum $i\left(p_{i}=n_{i} / N\right)$, where $n_{i}$ is the frequency of each prey taxum and $N$ is the total number of prey items found. $S$ is the number of prey taxa. A saturation curve was drawn by accumulation of diet diversity calculated for every four stomachs and appropriate sample size estimated with the stabilization of the curve (Castién and Gosálbez 1995).

Seasonal variation of the diet was represented as a new matrix, where the columns are expressed in terms of frequency of the prey taxa consumed every two months, and grouped according to the distribution of the rain pattern (dry and wet months). The rows are different prey taxa found in the diet. The bimonthly importance value of each food type is a weight frequency of the number of prey items per stomach related to the total of digestive tracts studied. Finally, seasonal and sex variations of the diet were compared by Spearman's rank correlation. Statistical tests for seasonal variation in the diet were run using all data bases and only the main prey taxum. SPSS/PC statistical package was employed to perform the analysis (Norusis 1992).

\section{Results}

Stabilization of the diversity saturation curve was obtained on the basis of 12 alimentary tract contents (Fig. 3). Thus it was possible to conclude that the sample studied was representative of the species' diet. The diet of male and female was significantly correlated $(r=0.54, p<0.005)$, showing that there were no differences between the diet of the two sexes. Similarly, the diet between the wet and dry season were also significantly correlated $(r=0.90, p<0.001 ; r=0.95 p<0.001$ respectively), and again, there were no differences in the diet composition between

Fig. 3. Cumulative diversity index of prey items from the alimentary tracts of Cryptotis meridensis.

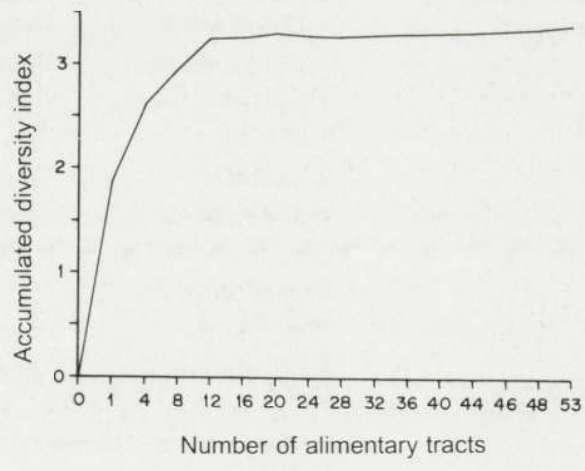


Table 1. Diet composition of Cryptotis meridensis. MH - microhabitat used per each prey taxum, $\mathrm{N}-$ frequency of each prey type, A - percentage of prey items, B - percentage by each taxonomic order, C percentage of individuals having eaten the prey taxum, Un - unidentified, La - larvae, $\mathrm{Pu}$ - pupae.

\begin{tabular}{|c|c|c|c|c|c|c|}
\hline Class/order & Family & MH & $\mathrm{N}$ & A & B & $\mathrm{C}$ \\
\hline \multicolumn{7}{|l|}{ Gastropoda } \\
\hline \multirow[t]{2}{*}{ Pulmonata } & Limacidae & Hypogeal & 12 & 1.65 & 3.99 & 18.18 \\
\hline & Helicidae & Hypogeal & 17 & 2.34 & & 30.91 \\
\hline \multicolumn{7}{|l|}{ Annelida } \\
\hline Oligochaeta & & Hypogeal & 61 & 8.39 & 8.39 & 74.65 \\
\hline \multicolumn{7}{|l|}{ Arachnida } \\
\hline \multirow[t]{4}{*}{ Araneae } & Dipluridae & Hypogeal & 15 & 2.06 & 9.07 & 14.55 \\
\hline & Theraphosidae & Hypogeal & 19 & 2.61 & & 21.82 \\
\hline & Lycosidae & Epigeal & 27 & 3.71 & & 41.82 \\
\hline & Ctenidae & Epigeal & 5 & 0.69 & & 7.27 \\
\hline Acarina & & Hypogeal & 11 & 1.51 & 1.51 & 14.55 \\
\hline \multicolumn{7}{|l|}{ Crustacea } \\
\hline Isopoda & & Hypogeal & 28 & 3.85 & 3.85 & 27.27 \\
\hline \multicolumn{7}{|l|}{ Myriapoda } \\
\hline Chilopoda & Scolopendridae & Hypogeal & 21 & 2.89 & 2.89 & 30.91 \\
\hline \multicolumn{7}{|l|}{ Insecta } \\
\hline \multirow[t]{5}{*}{ Orthoptera } & Acrididae & Epigeal & 51 & 7.02 & 21.60 & 50.91 \\
\hline & Gryllidae & Epigeal & 49 & 6.74 & & 58.18 \\
\hline & Tettigoniidae & Epigeal & 12 & 1.65 & & 18.18 \\
\hline & Phasmatidae & Hypogeal & 15 & 2.06 & & 23.64 \\
\hline & Blattidae & Hypogeal & 30 & 4.13 & & 38.18 \\
\hline \multirow[t]{2}{*}{ Hemiptera } & Coreidae & Epigeal & 4 & 0.55 & 1.51 & 7.27 \\
\hline & Pentatomidae & Epigeal & 7 & 0.96 & & 10.91 \\
\hline \multirow[t]{3}{*}{ Lepidoptera } & Sphingidae $(\mathrm{Pu})$ & Hypogeal & 17 & 2.34 & 8.25 & 27.27 \\
\hline & Lepidoptera (La) & Hypogeal & 11 & 1.51 & & 14.55 \\
\hline & Lepidoptera $(\mathrm{Pu})$ & Hypogeal & 32 & 4.40 & & 40.00 \\
\hline \multirow[t]{2}{*}{ Diptera } & Tachinidae & Epigeal & 2 & 0.28 & 3.99 & 3.64 \\
\hline & Diptera (La) & Hypogeal & 27 & 3.71 & & 32.73 \\
\hline \multirow[t]{10}{*}{ Coleoptera } & Carabidae & Hypogeal & 28 & 3.85 & 30.25 & 29.09 \\
\hline & Tenebrionidae & Hypogeal & 15 & 2.06 & & 16.36 \\
\hline & Lampyridae & Hypogeal & 19 & 2.61 & & 18.18 \\
\hline & Staphylinidae & Hypogeal & 23 & 3.16 & & 25.45 \\
\hline & Elateridae (La) & Hypogeal & 28 & 3.85 & & 36.36 \\
\hline & Passalidae & Hypogeal & 14 & 1.93 & & 21.82 \\
\hline & Lucanidae & Epigeal & 5 & 0.69 & & 7.27 \\
\hline & Scarabaeidae & Epigeal & 31 & 4.26 & & 40.00 \\
\hline & Scarabaeidae(La) & Hypogeal & 46 & 6.33 & & 52.73 \\
\hline & Coleoptera (Un) & - & 11 & 1.51 & & 14.55 \\
\hline \multirow[t]{2}{*}{ Hymenoptera } & Formicidae & Hypogeal & 16 & 2.20 & 2.89 & 14.55 \\
\hline & Ichneumonidae & Epigeal & 5 & 0.69 & & 7.27 \\
\hline Un insects & & - & 13 & 1.79 & 1.79 & 18.18 \\
\hline
\end{tabular}


the two seasons. The lack of intersexual and seasonal differences led us to pool the data. The relative importance of different prey taxum is given in Table 1, based on the percentage of dietary occurrences of each prey (column A) and the percentage of shrews having eaten each prey category (column C).

Thirty-five prey categories at the family level were identified from the dietary analysis of $C$. meridensis. These families belonged to six different classes and twelve orders. The average $( \pm \mathrm{SD})$ number of prey items in each digestive tract was $12.82 \pm 3.42$ and the number of different prey taxa ingested per each shrew was of $9.40 \pm 2.29$.

Oligochaeta made up the highest contribution of $8.39 \%$ to the overall diet (Table 1 , column A) and the high percentage of shrews eating earthworms (74.65\%) increased their importance as a food resource (column C). Hypogeal Gastropoda was also found in a relative, large proportion (3.99\%) of the total diet (column B). Snails (Helicidae) represented $2.34 \%$ of the overall diet (column A) and they were eaten by $30.91 \%$ of the shrews (column C). Slugs from Limacidae family were found in smaller proportion of $1.65 \%$ and they were eaten by only $18.18 \%$ of the shrews.

The two families Lycosidae (epigeal) and Theraphosidae (hypogeal) from the order Araneae were also important as a food resource to the shrew, representing $6.32 \%$ of the overall diet (column A). Lycosidae was found in a high proportion of $3.71 \%$ (column $\mathrm{A}$ ) and $41.82 \%$ of the shrews had included it in the diet (column C). However, Theraphosidae was a less important component of the diet $(2.61 \%)$ and $21.82 \%$ of the individuals had eaten this item (column C). Other hypogeal invertebrates were of relative importance making a variable contribution to the shrew diet: Isopoda formed $3.85 \%$ (column A) and $27.27 \%$ of the shrews had eaten it (column C). Scolopendridae made a contribution of $2.89 \%$ (column A) to the diet and a higher proportion (30.91\%) of the shrews consumed it (column C).

Amongst insects, the epigeal Orthoptera, which live mainly on the surface of leaf litter made an important contribution to the shrew diet. Acrididae was the most frequent taxum found in the stomach contents, representing $7.09 \%$ of the diet composition (column A). A high proportion $(50.91 \%)$ of individuals had eaten it (column C). The second most important taxum was Gryllidae with a percentage of $6.74 \%$ of the total diet (column A). However, a greater number $(58.18 \%$ ) of the shrews consumed it (column C). Hypogeal insects (Blattidae and Phasmatidae) were taken in smaller quantities. Blattidae made the larger contribution $(4.13 \%)$ to the diet (column A) and $38.18 \%$ of the individuals had consumed it (column C). However, Phasmatidae comprised only $2.06 \%$ of the diet and $23.64 \%$ of the shrews had eaten it.

Only the hypogeal life forms of Lepidoptera (larvae and pupae) and Diptera (larvae) were found in the digestive tracts. Many of them pupate in the interface between leaf litter and soil. Diptera larvae are the most common insects in leaf litter and decaying wood. The Lepidoptera represented a total of $8.25 \%$ of the diet (column B), almost the same value as for earthworms. Lepidoptera pupae found in the shrew digestive tracts belong to the hawkmoths (Sphingidae). A high proportion 
of shrews (72.84\%) consumed their larvae and pupae. Diptera larvae accounted for smaller quantities $(3.71 \%)$ of the diet (column A) and $32.73 \%$ of the shrews had taken this item as a food resource (column C).

The order Coleoptera was the most diverse taxonomic group found in the digestive tract of this shrew. Coleoptera probably have the greatest diversity of all soil-inhabiting species. Seven families of Coleoptera (adults and larvae) comprised $30.25 \%$ of the diet (column B), among them Scarabaeidae larvae represented $6.33 \%$ of it (column A). This item was eaten by $52.73 \%$ of the shrews (column C). Epigeal Scarabaeidae (adults) were also important in the composition of the diet. They made up $4.26 \%$ of the overall diet (column A) and $40.00 \%$ of the shrews consumed them (column C). Many of the epigeal form of Coleoptera such as: the click beetle larvae (Elateridae), the ground beetle (Carabidae) and the rove beetle (Staphylinidae) were also important to the diet, all of them forming $10.86 \%$ of it. Elateridae larvae were found in the same proportion $(3.85 \%)$ as Carabidae adults. However, Elateridae larvae were eaten by a higher proportion $(36.36 \%)$ of the shrews, compared to only $29.09 \%$ of Carabidae (column C).

The main prey taxa of $C$. meridensis were hypogeal invertebrates such as: Oligochaeta, Theraposidae, Isopoda, Scolopendridae, Phasmatidae, Blatiidae, Lepidoptera larvae and pupae, Diptera larvae, adult Carabidae, Staphilinidae, Elateridae larvae, Passalidae and Scarabaeidae larvae (Table 1). Their contribution was higher $69.44 \%$. Ephigeal invertebrates (Lycosidae, Acrididae, Gryllidae and adult Scarabaeidae) made up a smaller contribution accounting for only $21.24 \%$. Seventeen further taxa were found infrequently in the shrew diet.

Insects formed the bulk of the shrew diet and they are considered to be its main food resource, twenty-five prey taxa from this taxonomic group were included in its diet which represented $70.28 \%$ of it (Fig. 4A). Araneae were by four families accounted for $9.07 \%$ to the diet. However, Oligochaeta, which might include only one family, represented a higher proportion of the overall diet $(8.39 \%)$.

The majority of insects is made up of eight families of Coleoptera (44.63\%), five of Orthoptera accounting for $31.83 \%$ of the diet and at least one family of Lepidoptera comprised $12.17 \%$. The remaining four taxa only accounted for $12.37 \%$ of the overal diet (Fig. 4B).
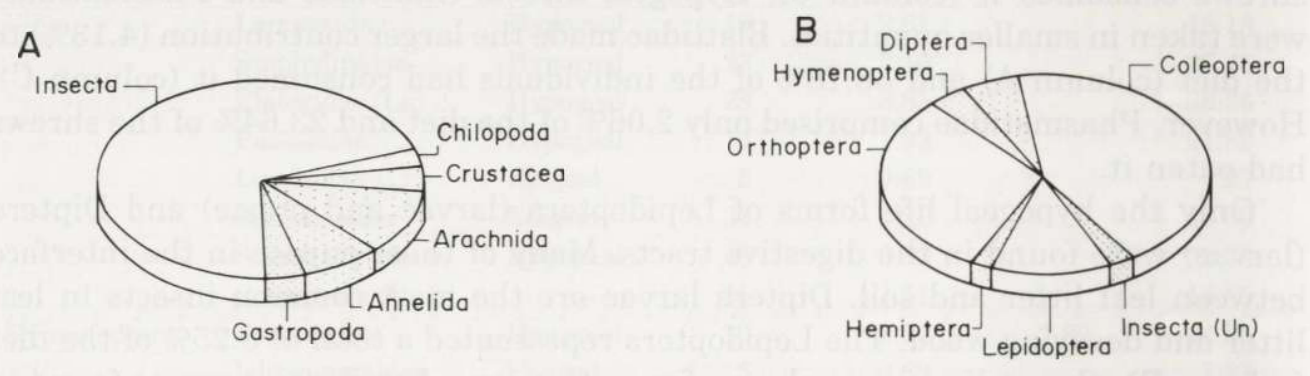

Fig. 4. Percentage composition of the diet of Cryptotis meridensis from the cloud forest of Monte Zerpa, Mérida, Venezuela. (A) Overall diet composition. (B) Insect orders present in the diet. 


\section{Discussion}

Cryptotis meridensis is a wide range feeder with its main diet consisting of hypogeal $(69.44 \%)$ and epigeal $(27.24 \%)$ invertebrates. A large proportion consists of earthworms (Oligochaeta), isopods, cockroaches (Blattidae), beetle larvae (Scarabaeidae and Elateridae), moths (larvae and pupae), snails (Helicidae), fly larvae (Diptera). Amongst epigeal, the more frequently found were the grasshoppers (Acrididae and Gryllidae), and hunting foliage spiders (Lycosidae). This is an indication that this shrew species is a more hypogeal than epigeal forager, confirming the morphological based prediction. This shrew burrows throughout the leaf litter, under logs and bases of hollow trees in the cloud forest or throughout the moss and lichen mat in the páramo (Durant and Péfaur 1984, Linares 1998), where it satisfies a great part of its food requirements and also finds protection from predators.

Based on the kinds of organisms found in the gut contents, the shrew diet is composed primarily of soil insects and the developmental stages of Lepidoptera and Coleoptera. Some other soil invertebrates such as earthworms, a single taxonomic group, were also an important component of the diet. Earthworms are one of the most abundant invertebrates in the forest floor, having high biomass relative to the other prey taxa and the largest proportion of shrews consumed them. Based on that information the importance of earthworms as food resource is increased considering their high biomass and energy value as well as their low content of indigestible chitin (Churchfield 1993). Their contribution by volume analysis would be higher than in terms of dietary occurrence. However, volume could exaggerate their importance because they may persist in the stomach longer than small prey (Schoener 1989).

Many terrestrial temperate and tropical shrew species feed on a large number of hypogeal and epigeal invertebrates according to their morphological adaptations. For example, in the shrew community of the taiga of Central Siberia a strong relationship was found between shrew size and the proportion of earthworms present in the diet. The larger-sized shrews such as Sorex roboratus and Sorex isodon (which are primarily hypogeal foragers) ate the largest proportion of this taxum The smaller-sized ones (S. minutissimus and $S$. minutus) never eat earthvorms, being more epigeal foragers (Churchfield and Sheftel 1994). In addition, the diet of $S$. araneus in three localities in Britain showed that dominant prey vas earthworms in all three areas and it confirmed its general hypogeal foraging mode (Rudge 1968, Pernetta 1976). S. cinereus and S. longirostris included a greater variety of hypogeal rather than epigeal invertebrates such as earthvorms, and insect larvae (Whitaker and Mumford 1972). Likewise, Sorex coronatus feeds on almost all available resources but shows a preference for soil invertebrates related to its subterranean mode of foraging (Castién and Gosálbez 1995). Cryptotis parva and Blarina brevicauda included higher proportion of earthvorms than other invertebrates in their diet (Whitaker and Mumford 1972). 
Studying the feeding behaviour of three species from the genus Crocidura in the desert of Namib, it was found that all species fed on insect larvae, Chilopoda, Isoptera and Araneae (Dickman 1995). A preliminary description of the diet of Cryptotis montivaga in Ecuador showed a composition of Lepidoptera larvae, Araneae and adult Coleoptera (Barnett 1992). However, the absence of quantitative data prevented a comparison between these two closely related species. The information presented here confirms that shrews are wide feeders, feeding on hypogeal and epigeal invertebrates according to their morphological adaptations.

C. meridensis shares similar food resources with Aepeomys lugens, a semifossorial, large-sized and wide range feeder (Díaz de Pascual 1994). A. lugens fed on 36 taxa of hypogeal and epigeal invertebrates from which Arachnida, Gryllidae, Acrididae and Scarabaeidae were the main food resources accounting for more than $50 \%$ of its overall diet. It also included high proportions of earthworms in its diet. However, competition for food is not expected between these two morphologically similar species due to differences in their preferred habitat: A. lugens is associated with the primary forest with thick vegetation coverage while $C$. meridensis selects more open and damp areas (Aagaard 1982, Díaz de Pascual 1993, 1994). Consequently, A. lugens exploits more epigeal than hypogeal invertebrates as a result of differences in habitat selection. Differences in foraging modes based on microhabitat selection have been also predicted for two coexisting water shrew species Neomys anomalus and Neomys fodiens (Rychlik 1997). Similarly, S. cinereus and S. longirostris, which have overlapping diet and same morphological adaptations, can coexist thanks to differences in their habitat selection (French 1984). Insectivorous mammals can coexist mainly because of differences in habitat selection, as was found in other insectivorous communities (Dickman 1988).

Our data did not show any significant seasonal variation in the diet of $C$. meridensis. However, we have found that the overall abundance of this species of shrew is highly correlated with the rainfall pattern (Mora et al. 1997). This relationship can be explained the reduction of their activity on the ground surface at the time of low precipitation. This, in turn, is associated with changes in the vertical distribution of earthworms, which migrate from the surface to the deeper layers of the soil during drought periods.

The diet of vertebrate insectivores has often been described as "opportunistic"; eating whatever they encounter and taking prey in the same proportions as it is found in the environment (Pernetta 1976). Without measuring environmental availability, it whether this species is a true opportunist cannot be evaluated. However, C. meridensis has a preference for hypogeal prey and its capacity for detecting subterranean prey might fail to show any relationship between abundance of prey and the diet of the shrew (Churchfield 1982, Dickman 1988).

Acknowledgements: We are grateful to the Council for Scientific, Humanistic and Technological Development of the University of The Andes (CDCHT) for financial aid given throughout Projects and to J. Pascual for his constant help with fieldwork. We are also grateful to E. T. Lunday for her writing courses given at the Venezuelan American English Center in Mérida (CEVAM) and her correction of our English. Finally, I would like to thank to Dr L. Rychlik for providing helpful comments on the manuscript. 


\section{References}

Aagaard E. M. 1982. Ecological distribution of mammals in the cloud forest and páramos of the Andes, Mérida, Venezuela. Ph D thesis, Colorado State University, Fort Collins: 1-276 +29.

Adis J. 1981. Comparative ecological studies of the terrestrial arthropod fauna in Central Amazonian inundation forest. Amazoniana 7: 87-173.

Adis J. 1988. On the abundance and density of terrestrial arthropods in Central Amazonian dry land forests. Journal of Tropical Ecology 4: 19-24.

Ataroff M. and Schwarzkopf T. 1992. Leaf production, reproductive patterns, field germination and seedling survival in Chamaedora bartlingiana, a dioecious understory palm. Oecologia 92: 250-256.

Barnett A. A. 1992. Notes on the ecology of Cryptotis montivaga Anthony, 1921 (Insectivora: Soricidae), a high-altitude shrew from Ecuador. Mammalia 56: 587-592.

Borror D. J. and DeLong D. M. 1981. An introduction to the study of insects. Holt, Rinehart and Winston, Inc., New York: 1-812.

Castién E. and Gosálbez J. 1995. Diet of Sorex coronatus in the western of Pyrenees. Acta Theriologica 40: $113-121$.

Chapman R. F. 1971. The insects, structure and function. American Elsevier Publishing Company, Inc., New York: 1-819.

Churchfield S. 1982. Food availability and the diet of the common shrew, Sorex araneus, in Britain. Journal of Animal Ecology 51: 15-28.

Churchfield S. 1993. Foraging strategies of shrews: interactions between small predators and their prey. [In: Mammals as predators. N. Dunstone and M. L. Gorman, eds]. 235-252.

Churchfield S. and Sheftel B. I. 1994. Food niche overlap and ecological separation in a multi-species community of shrews in the Siberian taiga. Journal of Zoology, London 234: 105-124.

Craig D. J. 1991. Temporal variation in diets and trophic partioning by coexisting lizards (Ctenotus: Scincidae) in central Australia. Oecologia 85: 553-561.

De Ascenção A. 1997. [Composition, structure, trophic characterization and temporal activity patterns of dung beetle community (Scarabaeoidea) in the cloud forest]. Lic. Thesis Universidad de Los Andes. Mérida, Venezuela: 1-127 + 31. [In Spanish]

Díaz de Pascual A. 1993. Habitat characterization of some small mammals in the cloud forest of Monte Zerpa. Mérida, Venezuela. Ecotrópicos 6: 1- 9. [In Spanish with English summary]

Díaz de Pascual A. 1994. The rodent community of the venezuelan cloud forest of Mérida. Polish Ecological Studies 20: 155-161.

Dickman C. R. 1988. Body size, prey size, and community structure in insectivorous mammals. Ecology 69: $569-580$

Dickman C. R. 1995. Diets and habitat preferences of three species of crocidurine shrews in arid southern Africa. Journal of Zoology, London 237: 499-514.

Duarte M. and Viloria A. 1992. New record of Cryptotis thomasi (Merrian, 1897) (Mammalia: Insectivora) in the "Sierra de Perijá" at the northeaster of the Colombian Andes range. Acta Científica Venezolana 43: 240-242. [In Spanish with English summary]

Durant P. 1993. [The cloud forest of Monte Zerpa]. [In: Wandering through the science. J. E. Péfaur and F. Fuenmayor, eds]. Facultad de Ciencias. Universidad de Los Andes. Mérida. Venezuela: 211-221. [In Spanish]

Durant P. and Péfaur J. 1984. [Systematic and ecology of the Shrew of Mérida. (Soricidae: Insectivora)]. Revista de Ecología y Conservación Ornitológica Latinoamericana 2: 3-16. [In Spanish]

French T. 1984. Dietary overlap of Sorex longirostris and S. cinereus in Hardwood floodplain habitats in Vigo County, Indiana. The American Midland Naturalist 111: 41- 46.

Handley C. and Kalko E. 1993. A short history of pitfall trapping in America, with a review of methods currently used for small mammals. Virginia Journal of Science 44: 19-26.

Hutterer R. 1985. Anatomical adaptations of shrews. Mammal Review 15: 43-55.

Kirkland G. L. Jr and Sheppard P. K. 1994. Proposed standard protocol for sampling small mammal communities. [In: Advances in the biology of shrews. J. Merritt, G. Kirkland Jr and R Rose, eds]. Carnegie Museum of Natural History Special Publication No 18, Pittsburgh: 277-281. 
Leigh E. Jr, Rand S. and Windsor D. 1982. The ecology of a tropical forest. Seasonal rhythms and long-term changes. [In: The Ecology of the tropical forest. E. Leigh Jr., S. Rand, and D. Windsor eds] Washington, D. C: Smithsonian Institution Press 355-387.

Levings S. and Windsor D. 1984. Litter moisture content as a determinant of litter arthropod distribution and abundance during the dry season on Barro Colorado Island, Panamá. Biotropica 16: $125-131$.

Linares O. J. 1998. [The Venezuelan mammals]. Audubon Conservation Society of Venezuela. Caracas: 1-691. [In Spanish]

López-Arévalo H., Montenegro-Díaz O. and Cadena A. 1993. Ecology of the small mammals of the Carpanta Biological Reserve, in the Colombian oriental range. Studies on Neotropical Fauna and Environment 28: 193-210. [In Spanish with English summary]

Metcalf C. L. and Flint W. P. 1985. [Destructive and useful insects, their behavior and their control]. McGraw-Hill Book Company, Inc., New York: 1-1208. [In Spanish]

Mora J., Díaz de Pascual A., Orlandoni G. and Márquez J. 1997. [Relationship between the relative abundance of four species of small mammals and the precipitation]. [In: Proceeding of the 5th Meeting of the International Biometric Society Network For Central America, The Caribean, México, Colombia y Venezuela]. Facultad de Estadística e Informática. Universidad Veracruzana. Xalapa: 395-404. [In Spanish]

Narváez Z. and Soriano P. 1996. Composition and structure of the Sphingidae community (Insecta: Lepidoptera) of the Andean cloud forest. Ecotrópicos 9: 9-20. [In Spanish with English summary]

Norusis M. J. 1992. SPSS for windows: Base system User's Guide Release 5.0. Chicago: 1- 672.

Osuna E. 1995. [Insect exoskeleton morphology]. Consejo de Desarrollo Científico y Humanístico. Universidad Central de Venezuela, Caracas: 1-471. [In Spanish]

Pernetta J. C. 1976. Diets of the shrews Sorex araneus L. and Sorex minutus L. in Wytham grassland. Journal of Animal Ecology 45: 899-912.

Pernetta J. C. 1977. Anatomical and behavioural specialization of shrews in relation to their diet. Canadian Journal of Zoology 55: 1442-1453.

Pielou E. 1975. Ecological Diversity. John Wiley and Sons, New York: 1-165.

Rose R. K. 1980. The southeastern shrew, Sorex longirostris, in southern Indiana. Journal of Mammalogy 61: 62-64.

Rudge M. R. 1968. The food of the common shrew Sorex araneus L. (Insectivora: Soricidae) in Britain. Journal of Animal Ecology 37: 565-581.

Rychlik L 1997. Differences in foraging behaviour between water shrews: Neomys anomalus and Neomys fodiens. Acta Theriologica 42: 351-386.

Schoener T. W. 1989. Should hindgut contents be included in lizard dietary compilations ? Journal of Herpetology. 23: 455-458.

Smith R. F. and Silva G. 1983. [Identification Keys for Neotropical terrestrial arthropods]. Universidad Centrooccidental "Lisandro Alvarado" of Venezuela, Barquisimeto: 1-334. [In Spanish]

Soriano P. J., Díaz de Pascual A., Ochoa J. and Aguilera M. 1999. Biogeographic analysis of the mammal communities in the Venezuelan Andes. Interciencia 24: 17-25.

Whitaker J. O. Jr 1988. Food habits analysis of insectivorous bats. [In: Ecological and behavioral methods for the study of bats. T. H. Kunz, eds]. Smithsonian Institution Press. Washington: 171-189.

Whitaker J. O. Jr and Mumford R. E. 1972. Food and ectoparasites of Indiana shrews. Journal of Mammalogy 53: 329-335.

Wolda H. 1981. Seasonality of tropical insects. II. Blattaria in Panama. Journal of Animal Ecology 50: 827-838.

Received 1 February 1998, accepted 16 August 1999. 